\title{
URBAN MOSQUE IN THE COMPACT CITY OF KUALA LUMPUR: SUITABILITY AND DESIGN CONSIDERATIONS
}

\author{
Nayeem ASIF ${ }^{2 *}$, Nangkula UTABERTA ${ }^{2}$, Arman SARRAM
}

DOI: 10.21163/GT_2019.141.27

\begin{abstract}
:
The government expects the population in Greater Kuala Lumpur will grow up to $10,000,000$ by 2020 under the Economic Transformation Programme (ETP). The development of Malaysia is now guided by the national agenda and Vision 2020 that envisions Malaysia as a fully developed country economically, socially, politically and spiritually. Religious facility requirement for Vision 2020 states 309 new mosques have to be established to fulfill the need of the growing population. While the land constraints remain for the city of Kuala Lumpur, the necessity of the ever increasing population cannot be overlooked. This necessitates developing an innovative tool which can provide a layout for maximizing the space use within the limited boundary. This paper studies the current space use patterns and formulates design framework for the mosque as a community center in the urban fabric of Kuala Lumpur. The research method is a combination of a qualitative and quantitative approach. The sample consisted of mosques in Kuala Lumpur, and data collection technique was semi-structured interview and observation. Effective and efficient community development functions are expected from the Institution of the mosque as a community center which can enhance not only to serve and strengthen the relationship of the Muslim community but also strengthen the ties of Malaysia's multiracial society as a whole.
\end{abstract}

Key-words: Urban mosque, Urban design, Compact city, Kuala Lumpur.

\section{INTRODUCTION}

Mosques are a vital part of every Islamic society and are primarily a place where spiritual and social connections among Muslims are expressed and established. In a historical context, a mosque in a sizeable community has a significant influence beyond religious focus into most, if not all aspects of the life of the community. The mosque is the place where people can have privacy with God, a place for reflection and prayer (Raeisian $\&$ Badreh, 2013). Over the years of transformation that Muslim society underwent, mosques have also taken many roles apart from its main spiritual function. "From rudimentary roles, it evolved into a complex and institutional one" (Omer, 2012). It is not solely a place of prayer but also a venue where the city's interaction takes place; it is a site for preaching and learning and a place of refuge where community work is also done (Morris, 2013). Architecturally, it is a structure uniquely Islamic which over time has evolved based on the socio-economic influences of eras, technological development and arising needs of the population and the environment.

1 UCSI University, Taman Connaught, 56000 Kuala Lumpur, Wilayah Persekutuan Kuala Lumpur, nayeem.asif@gmail.com;

2 Halal Products and Research Institute, Universiti Putra Malaysia, Selangor, Malaysia, nangkulautaberta@gmail.com

3 Limkokwing University of Creative Technology, Cyberjaya, 63000 Cyberjaya, Selangor, armanshure@gmail.com 
Urban enclaves such as compact cities are prime examples that display the modern transformation in mosques, showing its adaptation with the environment, consideration of urban lifestyle changes, innovation of use of space, optimizing functionality and maintaining overall aesthetic presentation of the structure. The urban mosque is a fairly new concept; it is described as "a new type of institution that presents a particular image of the urban design, spatial diversity and the use of public space" (Kahera, 2002).

According to (Asoka, Thuo, \& Bunyasi, 2013), the rapid population growth of cities is often associated with population demands that outdo the infrastructure and service capacity thus leading to environmental degradation. Similarly, it also affects efficient management from the government, rising costs in building and maintenance and most importantly a farreaching impact to future generations to come.

The same consideration must be therefore applied to infrastructures vital to the community such as mosques. In a compact city setting, expansion must be considered in the context of a vertical development which is

(1) within the boundaries of its intended capacity,

(2) the needs of the population, and

(3) serving and sustaining the function of the infrastructure whilst preserving the traditional and /or aesthetic style natural to the structure.

Reports on mosques in Malaysia as well as Indonesia showed that the mosques in these regions are devoid of diversified activities and innovative design which result in poor performance in terms of resource utilization and community development. (Rasdi \& Utaberta, 2010; Utaberta, 2009). It necessitates the study on an urban mosque to come up with a framework that will be suitable for monitoring the planning, design as well as performance of mosques within its urban fabric. Here, the notion of the urban fabric refers to the physical elements that essentially give shape to a particular urban area as stated by (La Rosa, Takatori, Shimizu, \& Privitera, 2018).

This study, therefore, attempts to evaluate modern urban mosque architecture in a compact city setting to assess on the sensibility of its designs as well as important address issues relative to its purpose and how it can be improved for further optimal use.

\section{DEFINING COMPACT CITIES}

The definition of a compact city is varied and defined more based on its characteristics by urban and environmental planners and organizations. The origin of the compact city is mentioned to date back during the fortress cities of the 16th century, which were made for protection from attack of a foreign enemy. The purpose of the compact city similarly varies from age to age (Kaji, Kanegae, Ishibashi, \& Hara, 2003).

By modern times, however, it is aimed at a sustainable society which is based on three principles. See (Dantzig \& Saaty, 1978) Compact city characteristics below.

\section{Urban Form}

(1) High dense settlements

(2) Less dependence on the automobile (high density)

(3) The clear boundary from surrounding areas

Spatial Characteristics

(4) Mixed land use

(5) The diversity of life (mixed-land use)

(6) Clear identity 


\section{Social Functions}

(7) Social fairness (high dense settlements)

(8) Self-sufficiency of daily life

(9) Independence of government (clear boundary)

Modern life, especially in urbanized areas, is associated with the usual issues of congestion, space constraints and socio-economic problems which makes planning and design a vital aspect in developing compact urban areas (Neuman, 2005). It should be viewed and approached with the perspective of sustainability within the context of modern culture and lifestyle (Barrett, 2000; Shaari, Abdullah Mohd Asmoni, Afiq Lokman, Abdul Hamid, \& Mohammed, 2015).

\section{DEVELOPMENT OF A MOSQUE WITHIN COMPACT CITIES}

In recent years, the concept of urban development has led to sustainable urban growth, in both micro and macro levels (Zavadskas, Kaklauskas, Vainiūnas, \& Šaparauskas, 2004). The quality of life is directly related to the quality of the environment, and therefore space and its structures can change and transform the quality of life. It changes communication networks, social and economic development aspects of society and more importantly the influence the reaction of the population (Gomis \& Turón, 2018).

Religious buildings, including temples, churches, synagogues, and mosques have always been one of the integral components of the urban layout (Ayhan \& Mert Cubukcu, 2010). The Mosque as a vital part of a Muslim majority area, therefore, helps support the change process. Its existences as part of the urban landscape (1) improve quality of life and (2) fosters growth within the community in the social, moral and even economic sense (Ziari, 2003). Al-Hathloul (2004) noted from his study of the Islamic literature that the city should have a congregation mosque, masjid al-Jami, in which the Friday sermon was given and in which the city's residents and its surroundings were served. This importance was first established by the construction of the Prophet's mosque in Madinah (Asif et al., 2015). The mosque served both as a place of worship and as a community center for the city, and thus played an essential function in the formation of the new society (Asif, Utaberta, Sarram, \& Ismail, 2018; Rasdi \& Utaberta, 2010).

This study focuses on the relationship of urban mosques with their surrounding environment in terms of activity pattern, space usage, and functional efficiency. Due to its genre, the study adopts a case study as a qualitative research strategy. The study is based on the evaluation of three mosques as case studies from Malaysia as primary data source all of which are located within the boundary of Zone 3 in Kuala Lumpur Federal Territory. The study's parameters are based on the location, which is a compact city, architectural features, and design of the mosque, functions, and activities.

Method for collecting data was semi-structured interview from related administrative persons and observation on the physical layout of the mosques. It is to be noted that interview of administrative personnel rather than the users of the mosques enables the researcher to obtain more reliable data in a relatively shorter period. Therefore, three administrative persons, who are the Imams of the respective mosque, were interviewed during the session of data collection. Analysis technique used for the collected data is content analysis with descriptive writing. 


\section{STUDY CASES}

Based on the surroundings, limitation of land and vertical approach of design Masjid Jamek Kg. Baru and Masjid Jamek Pakistan have been selected. As the central administrative zone for all the mosques in zone 3, Masjid Al-Imam Asy-Shafie has also been selected for the study. Moreover, Masjid Al-Imam Asy-Shafie will allow creating contrast with the other two cases in light of the existing scenario.

\subsection{Masjid Al-Imam Asy-Shafie}

Masjid Al-Imam Ash-Shafie is a mosque in the Maluri neighborhood of Cheras, Kuala Lumpur. Its prayer hall has a pyramid-shaped hip roof topped with a cup-shaped dome. The mosque also has a tall minaret with a pointed top. It is located along Jalan Perkasa. This mosque is also attached with the Pusat Pejabat for Zone 3, and the total land area is approximately $8750 \mathrm{~m}^{2}$. The figure below (Fig. 1) shows the basic layout of Masjid AlImam Asy-Shafie. Here (M) denotes space for male users, $(\mathrm{F})$ denotes space for female users and (EX) denotes extended space.

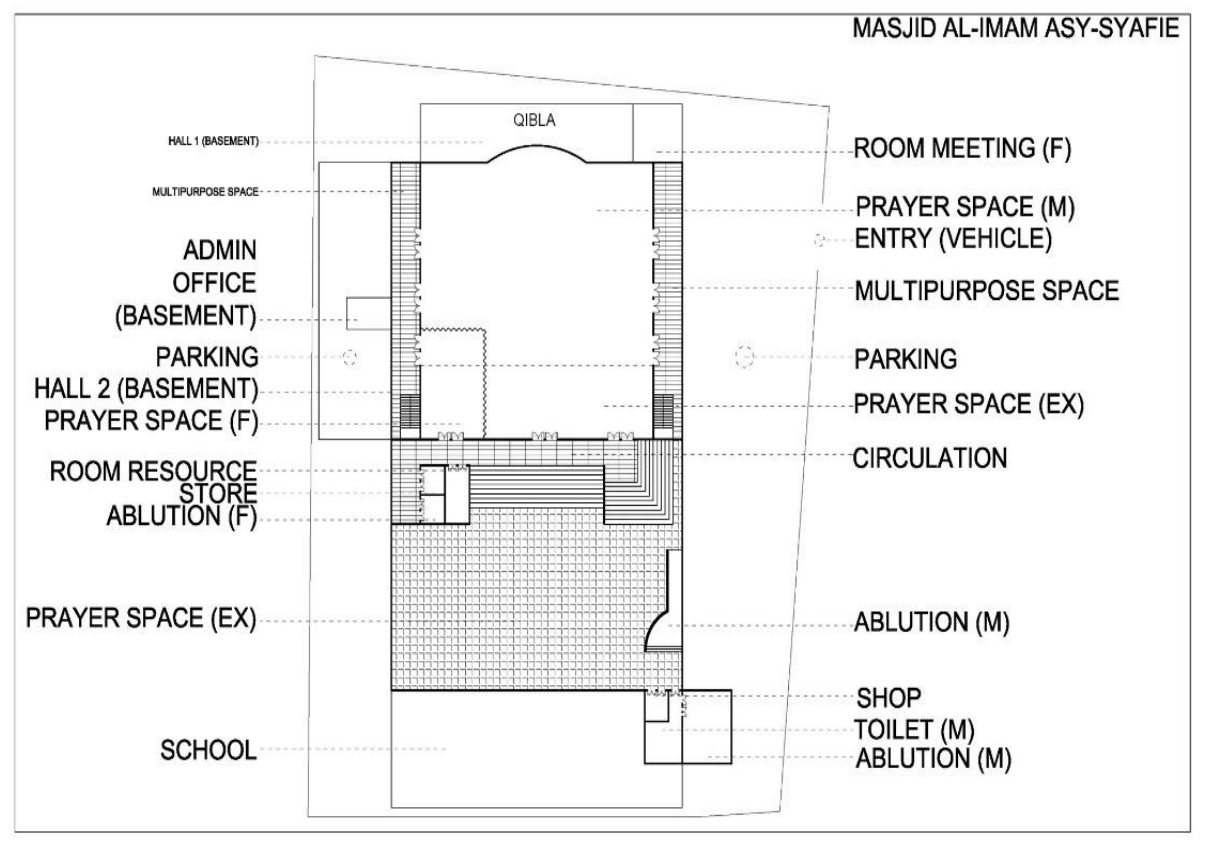

Fig. 1. Layout of Masjid Al-Imam Asy-Shafie. [Source: Author]

\subsection{Masjid Jamek Kg. Baru}

Masjid Jamek Kampung Baru or summarized JKB located on a piece of land which is also quite wide (about four lots) in Jalan Raja Alang, Kampung Baru, Kuala Lumpur 50300. Today, the Masjid Jamek Kampung Baru had to accommodate more than 7,000 worshipers every Friday and when the prayer is not less than 500 people in the congregation. This amount increased from day to day. The mosque (Fig. 2) is physically measuring 69.665 square feet or $6,472 \mathrm{~m}^{2}$. 


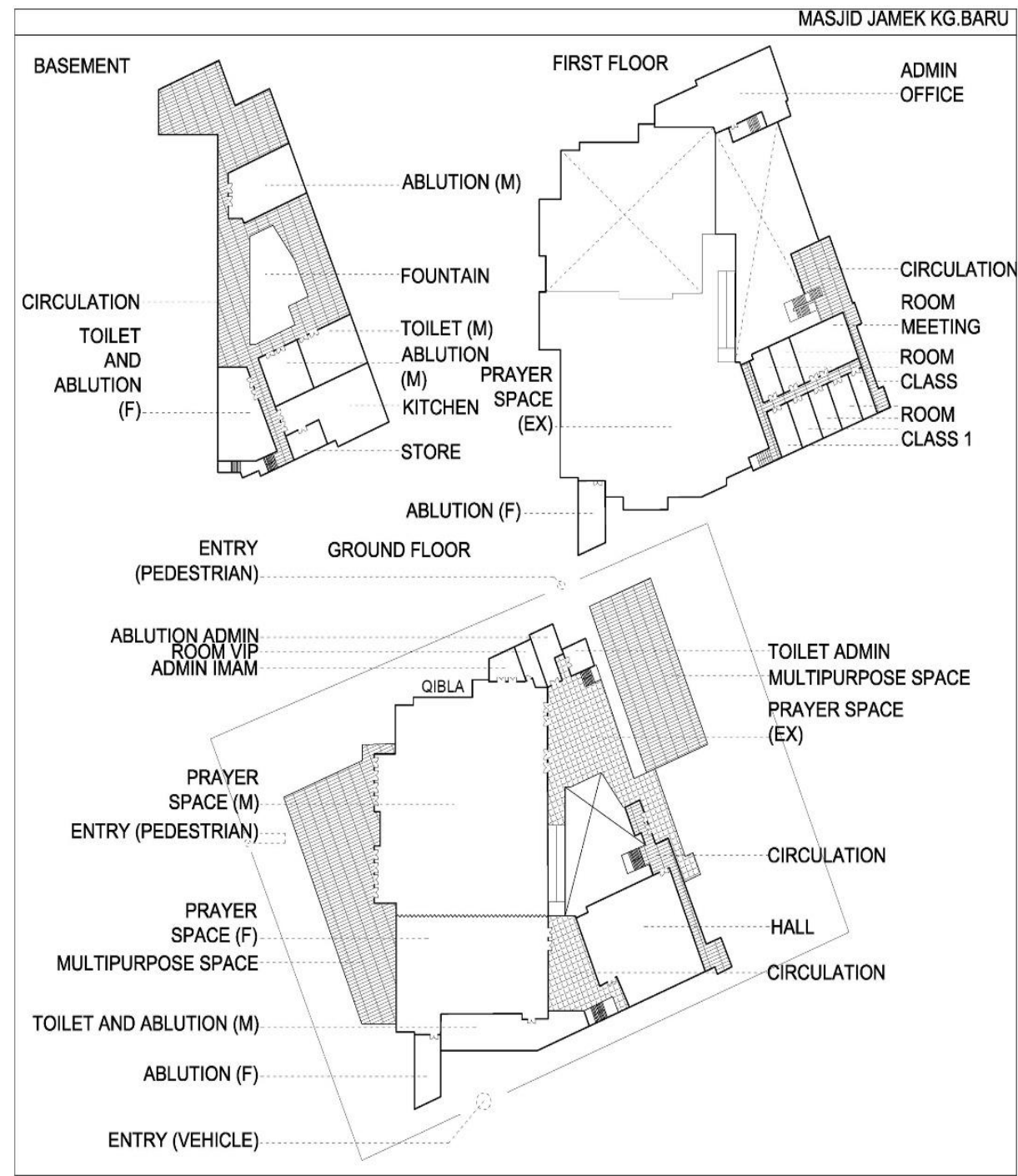

Fig. 2. Layout of Masjid Jamek Kampung Baru [Source: Author].

\subsection{Masjid Jamek Pakistan}

One of the two mosques in Kuala Lumpur that gives Friday sermons in a language other than Bahasa Malaysia is Masjid Jamek India. Masjid Jamek Pakistan is situated at an area where there is big community of Pakistani people. The location is filled with food stalls of Pakistani origin and always crowded with people. During Friday prayers or special Islamic occasions, the mosque becomes filled with Muslims from around the community so much so that some people have to pray outside the masjid perimeter, on the street. 


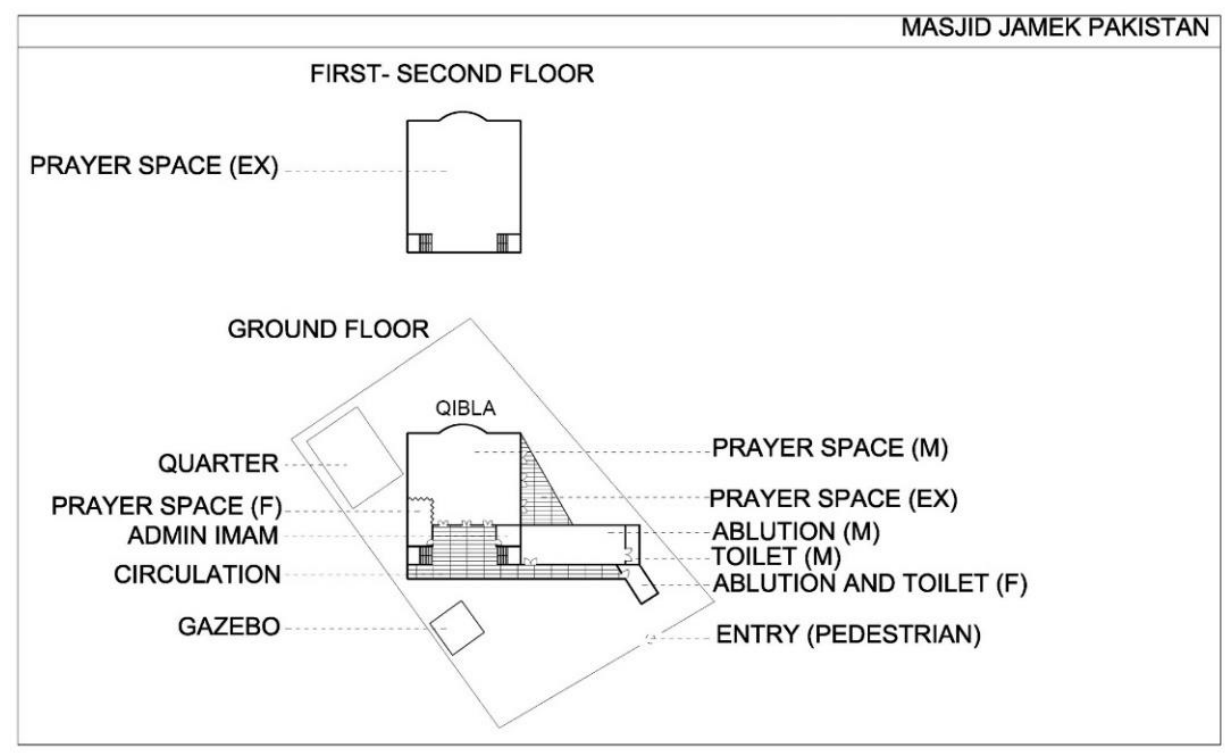

Fig. 3. Layout Masjid Jamek Pakistan [Source: Author].

The chart below (Fig. 4) compares the capacity of three mosques. The data on land area and prayer capacity were collected from the semi-structured interview.

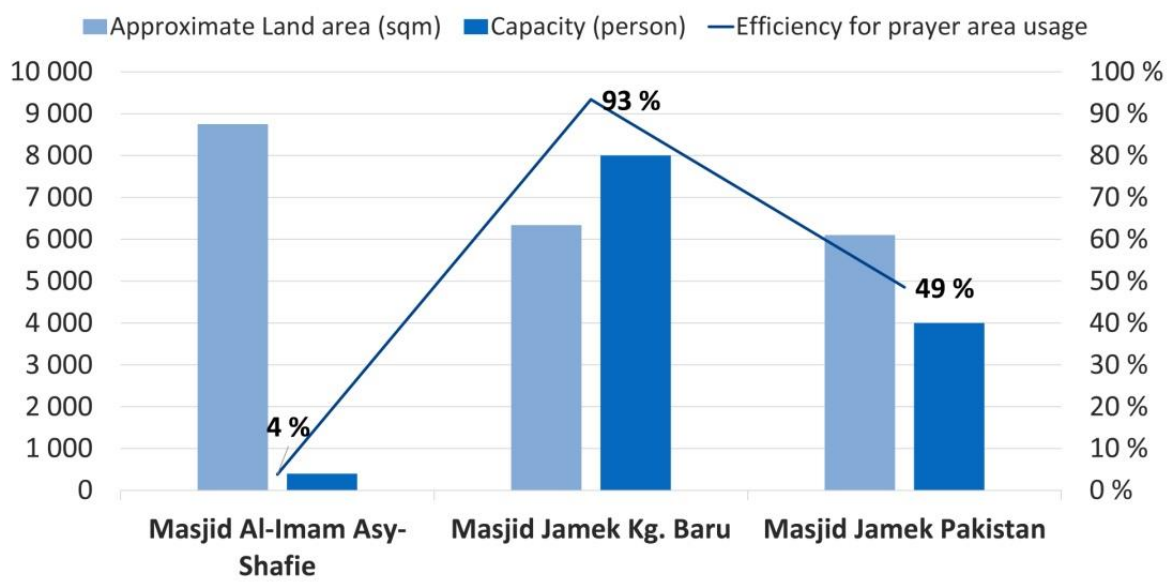

Fig. 4. Comparative chart of the capacity of selected mosques.

The chart shows that despite having a larger land area, Masjid Al-Imam Asy-Syafie has a lower capacity for prayer and it is due to its horizontal layout of planning. While Masjid Jamek Kg. Baru has smaller land compared to the former mosque, but because of its vertical stacking of spaces, it has higher prayer capacity. Masjid Jamek Pakistan illustrates a similar situation, and it is also planned vertically. Efficiency for the prayer area usage for these mosques is respectively $4 \%, 93 \%$, and $49 \%$. The chart clearly shows that horizontal 
and vertical progression of layout can create wide difference in land use efficiency as well as efficiency in prayer area usage. Now, the table below shows the list of spaces of this mosque and the programs associated with those spaces.

Table 1. List of spaces and activities.

\begin{tabular}{|c|c|c|}
\hline Mosque & List of Spaces & List of activities \\
\hline $\begin{array}{l}\text { Masjid Al- } \\
\text { Imam Asy- } \\
\text { Shafie }\end{array}$ & $\begin{array}{l}\text { Prayer space } \\
\text { Prayer space for women } \\
\text { Main office of Pusat Pejabat Zone } 3 \\
\text { The main office of Mosque } \\
\text { Primary school (Religious) } \\
\text { Kitchen } \\
\text { Dining Hall } \\
\text { Ablution area } \\
\text { Canteen } \\
\text { Multipurpose hall } \\
\text { Dewan Perkasa (Hall } 1 \text { and 2) }\end{array}$ & $\begin{array}{l}\text { Maghrib Lectures } \\
\text { Lecture for Muslimah } \\
\text { Public lecture } \\
\text { Occasional Feast } \\
\text { Ramadan lecture series }\end{array}$ \\
\hline $\begin{array}{l}\text { Masjid } \\
\text { Jamek Kg. } \\
\text { Baru }\end{array}$ & $\begin{array}{l}\text { Prayer Space }(\mathrm{GF}+1 \text { st Floor }) \\
\text { Prayer Space (Female) } \\
\text { Classroom } \\
\text { Meeting Room (Middle) } \\
\text { Foyer (Multipurpose- Prayer + Event) } \\
\text { Funeral Room } \\
\text { Meeting Room } \\
\text { Discussion Room } \\
\text { Ablution area }\end{array}$ & $\begin{array}{l}\text { Fajr and Maghrib Lectures } \\
\text { Islamic Day } \\
\text { (Lecture @ Forum) } \\
\text { Memorization of Quran } \\
\text { Lecture for Muslimah } \\
\text { IPT's Program } \\
\text { Seminar for Students' Development } \\
\text { Convention on Inspiration from } \\
\text { Khadija (RA) } \\
\text { Donation programs for Aid-al-Fitr } \\
\text { Intellectual Discourse }\end{array}$ \\
\hline $\begin{array}{l}\text { Masjid } \\
\text { Jamek } \\
\text { Pakistan }\end{array}$ & $\begin{array}{l}\text { Prayer Space (Main) } \\
\text { Prayer Space (Female) } \\
\text { Prayer Space (Upper stories) } \\
\text { Veranda } \\
\text { Ablution and Toilet (M/F) } \\
\text { Imam's Room } \\
\text { Gazebo }\end{array}$ & $\begin{array}{l}\text { Lecture on the Quran (Urdu) } \\
\text { Quran Translation (Urdu) } \\
\text { Quran Class } \\
\text { Urdu) } \\
\text { Special Khutba on Friday (Urdu) } \\
\text { Lecture on the Quran } \\
\text { Lailatul Barat (Dua and Lecture) } \\
\text { Prophet's (PBUH) Birthday } \\
\text { (Maulidur Rasul) } \\
\text { Iftar (Berbuka Puasa) } \\
\text { Marriage (Only for Foreigners, not } \\
\text { Malaysian) }\end{array}$ \\
\hline
\end{tabular}

It is to be noted that Masjid Al-Imam Asy-Shafie has more elaborate spaces than the other two mosques as this mosque also functions as the Pusat Pejabat for Zone 3. However, comparing the activities for these mosques, Masjid Al-Imam Asy-Shafie has less number of activities than Masjid Jamek Kg. Baru and Masjid Jamek Pakistan. 


\section{DISCUSSION AND RECOMMENDATION}

The discussion above shows that all the study cases serve various functions apart from the primary activity of a mosque which is religious rituals. The expectation of community from a contemporary mosque in urban area defines the programs and functions which must be accommodated within the mosque. Hence the planning and design of these mosques play a significant role to ensure all these activate can be accommodated within the constraints of land area.

Another key observation among all the mosques was their evolution from a simple function to that of multipurpose one. This showed that the mosque has expanded not only to religious service but also other areas which can serve the community. Other aspects such as education, social welfare assistance, community service, law and even the economic one are now included in the responsibilities of the mosque. Spatial topology, especially for the latter-day renovations done on the mosque, was made in such way that it addresses practical accessibility, maximum accommodation of worshippers in every space usable in and outside the mosque while also being used for other purposes apart from religious worship.

Mosque in compact cities must, therefore, consider all elements of modern urban life with consideration to the importance of balancing an environmental friendly surrounding, intelligent use of space, use of technology and modern materials to maximize the potential of the structure to be used in the best possible way. From the discussion on the urban mosque, it is quite evident that every mosque in compact cities must consider some factors such as,

(1) vertical development with integrated spaces,

(2) visual and physical connections both horizontally and vertically,

(3) accessibility in design,

(4) flexible spaces designed for multipurpose activities,

(5) providing plaza areas to avoid congestion in design and

(6) use of online media to reach out to the community without necessitating to be physically present for basic information.

Retaining functionality and aesthetic quality requires innovative thinking and exploration of new design ideas. The aesthetic is a quality which varies in time and place and even from person to person. Nevertheless, innovation in design language and adaptation to the changing pattern of architectural design can ensure efficient output rather than replicating or repeating what is readily available.

\section{CONCLUSION AND FUTURE WORK}

This paper has discussed the design aspects of contemporary mosques in the compact city of Kuala Lumpur. It was found that the design characteristics of these mosques play an important role in society and community service which includes social and even political purposes. The results of this research have provided many insights on the evolution of the mosque and how it can be further improved to address modern challenges. Based on the evaluated mosques in this study, urban mosques are built and made to serve the fundamental purpose of the mosque; however, because of the other essential needs of the community it also serves other purposes which demonstrate the flexibility of mosque in serving the community such as social, economic and even political. This shows the relevance of urban mosque where space constraint an-going issue. Furthermore, the 
examples mosques both modern and old were able to demonstrate and retain functionality and aesthetic presentation while maximizing its space allotment.

\section{ACKNOWLEDGEMENT}

This study was conducted with the aid of FRGS 2018-1 [FRGS/1/2018/WAB03/UPM/02/3] granted by the Ministry of Higher Education, Malaysia. The authors also acknowledge the support of the SABE, UCSI University and Halal Product Research Institute, Universiti Putra Malaysia.

\section{R E F E R E N C E S}

Al-Hathloul, S. (2004) Planning in the Middle East, moving toward the future. Habitat International, 28(4), 641-643. https://doi.org/10.1016/j.habitatint.2004.04.004

Asif, N., Utaberta, N., Sarram, A., \& Ismail, S. (2018) Design framework for urban mosque in the city of Kuala Lumpur: A qualitative approach. International Journal of Architectural Research: ArchNet-IJAR, 12(3), 170. https://doi.org/10.26687/archnet-ijar.v12i3.1586

Asif, N., Utaberta, N., Yazid, M., Yunos, M., Ismail, N. A., \& Ismail, S. (2015) Inactive Mosques : The Crisis of Contemporary Muslim Communities. Advances in Environmental Biology, 9(April), 367-370.

Asoka, G. W. N., Thuo, A. D. M., \& Bunyasi, M. M. (2013) Effects of population growth on urban infrastructure and services: A case of Eastleigh neighborhood Nairobi, Kenya. Journal of Anthropology \& Archaeology, 1(1), 41-56.

Ayhan, I. \& Mert Cubukcu, K. (2010) Explaining historical urban development using the locations of mosques: A GIS/spatial statistics-based approach. Applied Geography, 30 (2), 229-238.

Barrett, P. (2000). Systems and relationships for construction quality. International Journal of Quality \& Reliability Management, 17(4/5), 377-392.

Dantzig, G. B., \& Saaty, T. L. (1978) Compact City: A Plan for a Livable Urban Environment. W.H.Freeman \& Co Ltd (March 1974).

Gomis, J., \& Turón, C. (2018) The "Base Map" for Urban Planning: Cartographic Representation as a Fundamental Tool for the Representation of the Town Plan. Geographia Technica, 13(1), 5261.

Kahera, A. I. (2002) Urban Enclaves, Muslim Identity and the Urban Mosque in America. Journal of Muslim Minority Affairs, 22(2), 369-380.

Kaji, H., Kanegae, H., Ishibashi, K., \& Hara, N. (2003) Compact City and Developing Countries - Is Compact City Approach Appropriate as an Urban Development Policy for Cities in Developing Countries? Montreal, Canada.

La Rosa, D., Takatori, C., Shimizu, H., \& Privitera, R. (2018) A planning framework to evaluate demands and preferences by different social groups for accessibility to urban greenspaces. Sustainable Cities and Society, 36, 346-362.

Morris, A. E. J. (2013). History of Urban Form Before the Industrial Revolution. Taylor \& Francis. Retrieved from https://books.google.com/books?id=nRBEAgAAQBAJ

Neuman, M. (2005). The Compact City Fallacy. Journal of Planning Education and Research, 25(1), $11-26$.

Omer, S. (2012) Institutional Decentralization in the History of Islamic Cities: The Role of Political and Religious Schism. Retrieved January 18, 2017, from http://medinanet.org/2012/10/institutional-decentralization-in-the-history-of-islamic-cities-therole-of-political-and-religious-schism/ [March 2019]

Raeisian, G., \& Badreh, M. (2013) The Role of Mosques in Urban Development. Journal of Civil Engineering and Urbanism, 3(3), 101-103. 
Rasdi, M. T. H. M., \& Utaberta, N. (2010) The Design of Mosques as Community Development Centers from the Perspective of the Sunna andWright's Organic Architecture. Journal of Islamic Architecture, 1(1), 1-7.

Shaari, N., Abdullah Mohd Asmoni, M. N., Afiq Lokman, M. A., Abdul Hamid, H., \& Mohammed, A. H. (2015) Practices For Project Quality Management Systems (Pqms) In Construction Project. Jurnal Teknologi, 77(26), 69-76.

Utaberta, N. (2009) The Development of 20th Century's Modern Islamic Architecture Thought in Nusantara. Universiti Teknologi Malaysia.

Zavadskas, E. K., Kaklauskas, A., Vainiūnas, P., \& Šaparauskas, J. (2004) A model of sustainable urban development formation. International Journal of Strategic Property Management, 8(4), 219-229.

Ziari, K. (2003). The socio. cultural changes originating from industrial revolution in spatial development of Tehran. Geography and Development, 1(1), 151-164. 